\title{
Apolipoprotein E polymorphism is associated with lower extremity deep venous thrombosis: color-flow Doppler ultrasound evaluation
}

\author{
ShuangLi Zhu ${ }^{1,2}$, ZhiGang Wang ${ }^{1 *}$, XiaoPing $\mathrm{Wu}^{3}$, Yan Shu ${ }^{3}$ and DunXiang $\mathrm{Lu}^{2}$
}

\begin{abstract}
Introduction: Apolipoprotein E (apoE) is a member of apolipoprotein family, and its gene polymorphisms seem to have some impact among patients with cardiovascular disease. However, its role in the lower extremity deep venous thrombosis (LEDVT) has not been well studied. The objective of this study was to investigate the potential association between APOE gene polymorphisms and LEDVT.

Materials and methods: A hospital-based case-control study was conducted in 300 patients with LEDVT by color-flow Doppler ultrasound and 300 age- and gender-matched healthy controls. Polymerase chain reaction restriction fragment length polymorphism (PCR-RFLP) assay was applied to assess the APOE gene polymorphisms.

Results: Patients with LEDVT had a significantly higher frequency of APOE E3/E4 genotype [odds ratio $(O R)=1.48$, $95 \%$ confidence interval $(C l)=1.05,2.10 ; P=0.03$ ] than healthy controls. When stratifying by family history of LEDVT, it was found that patients with positive family history of LEDVT had a significantly higher frequency of APOE E3/E4 genotype $(\mathrm{OR}=1.68,95 \% \mathrm{Cl}=1.04,0.95 ; P=2.70)$. When stratifying by smoking status, presence of varicose veins, type 2 diabetes mellitus and any hormone administration before, no significant differences were found in any groups.
\end{abstract}

Conclusion: Our study suggested that APOE E3/E4 genotype was associated with a higher LEDVT risk. Additional studies are needed to confirm this finding.

Keywords: Apolipoprotein E, Gene polymorphism, Lower extremity deep venous thrombosis, Case-control study

\section{Introduction}

The lower extremity deep venous thrombosis (LEDVT) and its complications remain a finding of high incidence in hospitalized patients [1]. The use of color-flow Doppler ultrasound has achieved a higher accuracy in diagnosis of LEDVT than clinical examination alone [1,2]. The advantages of color-flow Doppler ultrasound have also provided conditions to restart investigations concerning the incidence of bilateral LEDVT in patients with a single symptomatic limb $[1,3]$. LEDVT is a multifactorial medical problem with genetic and acquired risk factors playing in concert in its pathogenesis [4-8]. Strong genetic factors have been implicated in the aetiology of LEDVT $[9,10]$.

\footnotetext{
* Correspondence: zgwangzg@hotmail.com

'Institute of Ultrasound Imaging, The Second Affiliated Hospital, Chongqing Medical University, 76 Riverside Road, Yuzhong District, Chongqing 400010, P. R. China

Full list of author information is available at the end of the article
}

Apolipoprotein $\mathrm{E}$ (apoE) is a member of apolipoprotein family. $A P O E$ gene, located on the long arm of chromosome 19, codes for a 299-amino acid protein (apoE). ApoE is a polymorphic glycoprotein involved in cholesterol transport and cell membrane maintenance and repair $[11,12]$. APOE exists in three common allelic forms: $\mathrm{E} 2$, $\mathrm{E} 3$, and $\mathrm{E} 4$, giving six possible genotypes (E2/E2, E2/E3, $\mathrm{E} 2 / \mathrm{E} 4, \mathrm{E} 3 / \mathrm{E} 3, \mathrm{E} 3 / \mathrm{E} 4$ and E4/E4) [13-15]. APOE gene polymorphisms seem to have some impact among patients with cardiovascular disease [16-18].

Recently, a few studies with different results were performed to investigate the association between $A P O E$ gene polymorphisms and DVT $[19,20]$. However, its role in the LEDVT has not been well studied. The objective of this study was to investigate the potential association between $A P O E$ gene polymorphisms and LEDVT.

Ciomed Central

(n)

(c) 2014 Zhu et al.; licensee BioMed Central Ltd. This is an Open Access article distributed under the terms of the Creative Commons Attribution License (http://creativecommons.org/licenses/by/2.0), which permits unrestricted use, distribution, and reproduction in any medium, provided the original work is properly cited. The Creative Commons Public Domain Dedication waiver (http://creativecommons.org/publicdomain/zero/1.0/) applies to the data made available in this article, unless otherwise stated. 


\section{Materials and methods Study population}

A hospital-based case-control study was conducted in 300 patients with LEDVT and 300 age- and gendermatched healthy controls during the years 2010 to 2013 from the institute of ultrasound imaging in the second affiliated hospital of Chongqing Medical University, China. The diagnosis of LEDVT was made by combining the results of color-flow Doppler ultrasound, D-dimer levels, and phlebography. To confirm the diagnosis, two physicians reviewed the hospital records and validated each case. The healthy control subjects were matched with the patients for age and sex. Healthy control subjects were recruited from the Second Affiliated Hospital of Chongqing Medical University where they were attending a clinic for routine examination. The Ethical Committee of the Second Affiliated Hospital of Chongqing Medical University approved the study protocols, and all participants gave written informed consent according to the Declaration of Helsinki.

\section{DNA extraction and genotyping}

The commercially available Qiagen kit (QIAGEN Inc., Valencia, CA, USA) was used to extract DNA from peripheral blood leukocytes. Polymerase chain reaction restriction fragment length polymorphism (PCR-RFLP) assay was applied to assess the $A P O E$ gene polymorphisms. Based on the GenBank reference sequence, the PCR primers were as follows: sense, ACAGAATTCGCCCCGGCCTG GTACAC; antisense, TAAGCTTGGCACGGCTGTCCA AGGA. The amplified DNA was digested with Hha I at $37^{\circ} \mathrm{C}$ for 2 hours, and analyzed by $6 \%$ polyacrylamide gel electrophoresis (PAGE). For quality control, all genotyping personnel were blinded to clinical and imaging data.

\section{Statistical analysis}

The allele and genotype frequencies of $A P O E$ gene in patients were compared to controls by Chi-square test. The $P$ value of statistical significance was adjusted by Fisher's exact test where appropriate. We applied multivariate logistic regression to calculate crude and adjusted odds ratios (OR) and 95\% confidence intervals (CI) for the association between the APOE genotypes and LEDVT risk. The Hardy-Weinberg equilibrium was tested for goodness-of-fit chi-square test with one degree of freedom to compare the observed genotype frequencies among the subjects with the expected genotype frequencies. A $P$-value was considered significant at a level of $<0.05$. All analyses were performed with Stata software (College Park,Tex.).

\section{Results}

The demographical and clinical features of the participants were showed in Table 1 . The mean age was $51.7( \pm 10.7)$ years for the LEDVT cases and $52.0( \pm 11.9)$ years for the
Table 1 The demographical and clinical features of the participants

\begin{tabular}{lccc}
\hline & LEDVT & HC & $P$ \\
\hline Total no. & 300 & 300 & \\
Gender (Male/female) & $190 / 110$ & $185 / 115$ & 0.67 \\
Age (Year) & $51.7 \pm 10.7$ & $52.0 \pm 11.9$ & 0.75 \\
Smoking status (Ever/never) & $122 / 178$ & $116 / 184$ & 0.62 \\
Presence of varicose veins (YES/NO) & $72 / 228$ & $55 / 245$ & 0.09 \\
Type 2 diabetes mellitus (YES/NO) & $25 / 275$ & $14 / 286$ & 0.07 \\
Any hormone administration before & $30 / 270$ & $18 / 282$ & 0.07 \\
(YES/NO) & & & \\
Family history of LEDVT (Positive/negative) & $58 / 242$ & - & - \\
\hline
\end{tabular}

LEDVT, lower extremity deep venous thrombosis; $\mathrm{HC}$, healthy control.

controls. The $63.3 \%$ participants were male for the LEDVT cases and $61.7 \%$ for the controls. No significant differences were found between the patients and the controls in gender, age, smoking status, presence of varicose veins, type 2 diabetes mellitus and any hormone administration before (Table 1).

Patients with LEDVT had a significantly higher frequency of $A P O E \mathrm{E} 3 / \mathrm{E} 4$ genotype $(\mathrm{OR}=1.48,95 \% \mathrm{CI}=1.05$, 2.10; $P=0.03$ ) than healthy controls (Table 2). When stratifying by family history of LEDVT, it was found that patients with positive family history of LEDVT had a significantly higher frequency of $A P O E$ E3/E4 genotype ( $\mathrm{OR}=1.68,95 \% \mathrm{CI}=1.04,0.95 ; P=2.70)$ (Table 3 ). When stratifying by smoking status, presence of varicose veins, type 2 diabetes mellitus and any hormone administration before, no significant differences were found in any groups (Table 3).

\section{Discussion}

Many studies have been performed to investigate an association of genetic polymorphism and DVT. A casecontrol study found that subjects carrying endothelial

Table 2 Frequencies of $A P O E$ gene polymorphisms in LEDVT and HC groups

\begin{tabular}{ccccc}
\hline Genotype & LEDVT $\mathbf{n}(\%)$ & HC $\mathbf{n}(\%)$ & OR $(\mathbf{9 5} \% \mathbf{C l})$ & $\boldsymbol{P}$ \\
\hline E2/E2 & $3(1.0)$ & $2(0.7)$ & $1.51(0.25,9.07)$ & 0.66 \\
E2/E3 & $1(0.3)$ & $2(0.7)$ & $0.50(0.05,5.53)$ & 0.57 \\
E2/E4 & $1(0.3)$ & $2(0.7)$ & $0.50(0.05,5.53)$ & 0.57 \\
E3/E3 & $185(61.7)$ & $206(68.7)$ & $0.73(0.52,1.03)$ & 0.07 \\
E3/E4 & $105(35.0)$ & $80(26.6)$ & $1.48(1.05,2.10)$ & 0.03 \\
E4/E4 & $5(1.7)$ & $8(2.6)$ & $0.62(0.20,1.91)$ & 0.40 \\
E2 allele frequency & $8(1.3)$ & $8(1.3)$ & $1.00(0.37,2.68)$ & 1.00 \\
E3 allele frequency & $476(79.3)$ & $494(82.3)$ & $0.82(0.62,1.10)$ & 0.19 \\
E4 allele frequency & $116(19.3)$ & $98(16.3)$ & $1.23(0.91,1.65)$ & 0.18 \\
\hline
\end{tabular}

LEDVT, lower extremity deep venous thrombosis; $\mathrm{HC}$, healthy control; OR, odds ratio; $\mathrm{Cl}$, confidence interval. 
Table 3 Stratification analysis of APOE genotype frequency in LEDVT patients

\begin{tabular}{|c|c|c|c|c|c|c|c|c|c|c|c|c|c|}
\hline \multirow{2}{*}{ Variable } & \multirow{2}{*}{ Cases } & \multicolumn{2}{|c|}{ E2/E2 } & \multicolumn{2}{|c|}{ E2/E3 } & \multicolumn{2}{|c|}{ E2/E4 } & \multicolumn{2}{|c|}{ E3/E3 } & \multicolumn{2}{|c|}{ E3/E4 } & \multicolumn{2}{|c|}{ E4/E4 } \\
\hline & & n (\%) & $P$ & n (\%) & $P$ & n (\%) & $P$ & n (\%) & $P$ & n (\%) & $P$ & n (\%) & $P$ \\
\hline Smoking status & 300 & $3(1.0)$ & & $1(0.3)$ & & $1(0.3)$ & & $185(61.7)$ & & 105(35.0) & & $5(1.7)$ & \\
\hline Ever & 122 & $1(0.8)$ & 0.86 & $0(0)$ & 0.90 & $0(0)$ & 0.90 & $71(58.2)$ & 0.74 & 48(39.3) & 0.57 & $2(1.6)$ & 0.98 \\
\hline Never & 178 & $2(1.1)$ & 0.90 & $1(0.6)$ & 0.71 & $1(0.6)$ & 0.71 & $114(64.0)$ & 0.80 & $57(32.0)$ & 0.64 & $3(1.7)$ & 0.99 \\
\hline Presence of varicose veins & 300 & $3(1.0)$ & & $1(0.3)$ & & $1(0.3)$ & & 185(61.7) & & 105(35.0) & & $5(1.7)$ & \\
\hline YES & 72 & $1(1.4)$ & 0.78 & $0(0)$ & 0.84 & $0(0)$ & 0.84 & $45(62.5)$ & 0.95 & 25(34.7) & 0.98 & $1(1.4)$ & 0.87 \\
\hline NO & 228 & $2(0.9)$ & 0.89 & $1(0.4)$ & 0.85 & $1(0.4)$ & 0.85 & $140(61.4)$ & 0.98 & $80(35.1)$ & 0.99 & $4(1.8)$ & 0.94 \\
\hline Type 2 diabetes mellitus & 300 & $3(1.0)$ & & $1(0.3)$ & & $1(0.3)$ & & 185(61.7) & & 105(35.0) & & $5(1.7)$ & \\
\hline YES & 25 & $1(4.0)$ & 0.24 & $0(0)$ & 0.41 & $0(0)$ & 0.41 & $16(64.0)$ & 0.91 & $7(28.0)$ & 0.61 & $1(4.0)$ & 0.43 \\
\hline NO & 275 & $2(0.7)$ & 0.73 & $1(0.4)$ & 0.95 & $1(0.4)$ & 0.95 & 169(61.5) & 0.98 & 98(35.6) & 0.91 & $4(1.4)$ & 0.84 \\
\hline Any hormone administration before & 300 & $3(1.0)$ & & $1(0.3)$ & & $1(0.3)$ & & 185(61.7) & & 105(35.0) & & $5(1.7)$ & \\
\hline YES & 30 & $1(3.3)$ & 0.30 & $0(0)$ & 0.47 & $0(0)$ & 0.47 & $18(60.0)$ & 0.93 & $9(30.0)$ & 0.70 & $2(6.7)$ & 0.11 \\
\hline NO & 270 & $2(0.7)$ & 0.74 & $1(0.4)$ & 0.94 & $1(0.4)$ & 0.94 & 167(61.9) & 0.98 & $96(35.5)$ & 0.92 & $3(1.1)$ & 0.58 \\
\hline Family history of DVT & 300 & $3(1.0)$ & & $1(0.3)$ & & $1(0.3)$ & & 185(61.7) & & 105(35.0) & & $5(1.7)$ & \\
\hline Positive & 58 & $1(1.7)$ & 0.64 & $0(0)$ & 0.74 & $0(0)$ & 0.74 & 22(37.9) & 0.07 & $34(58.6)$ & 0.04 & $1(1.7)$ & 0.98 \\
\hline Negative & 242 & $2(0.8)$ & 0.84 & $1(0.4)$ & 0.88 & $1(0.4)$ & 0.88 & 163(67.4) & 0.52 & $71(29.3)$ & 0.32 & $4(1.7)$ & 0.99 \\
\hline
\end{tabular}

protein $\mathrm{C}$ receptor (EPCR) gene 6936AG genotype likely had an increased risk of DVT [21]. The 20210 A allele of the prothrombin gene was a common risk factor among Swedish outpatients with verified DVT [22]. A case control study found an excess of rare coding single-nucleotide variants of the ADAMTS13 gene in patients with DVT [23]. A homozygosity state for 20210A prothrombin variant in a young woman was a cause of DVT during pregnancy [24]. Susceptibility to DVT in North Indian Asian patients may be associated with some variants of nitric oxide synthase 3 (NOS3) gene [25]. A large casecontrol study found that factor XIII (FXIII) 34Leu carriers were associated with a slightly decreased DVT risk [26]. A case control study found that genetic variants in the F11 gene were risk factors for DVT among both Whites and Blacks [27]. A meta-analysis indicated that rs2227589 in the SERPINC1 gene, rs13146272 in the CYP4V2 gene and rs1613662 in the GP6 gene were risk factors for DVT among Whites [27]. A case control study concluded that the G534E-polymorphism of the gene encoding the factor VII-activating protease is a risk factor for DVT [28]. A case control study suggested that tumor necrosis factor alpha (TNF-alpha) -308A allele was association with the risk of DVT [29]. The rs4524 SNP in F5 was consistently associated with DVT in 3 large case-control studies [30]. A case control study suggested that factor V G1691A (Leiden) and A4070G (HR2 Haplotype) polymorphisms were independent risk factors for DVT [31,32].

The APOE gene polymorphisms were associated with many other diseases. The E4 allele of the APOE gene was associated with a worse lipid profile in the Brazilian urban population [33]. In the Tunisian population the
APOE E4 appears to be only indirectly involved in the severity of coronary artery disease [34]. E2 allele of the $A P O E$ gene polymorphism was predictive for obesity status in Roma minority population of Croatia [35]. A meta-analysis included 29 studies involving 2,737 CI cases and 2,689 controls suggested that APOE E4 allele was associated with an increased risk of developing cerebral infarction in Chinese population [36]. A meta-analysis of 45 studies including 13,940 cases and 16,364 controls found that $A P O E$ gene polymorphisms were associated with essential hypertension [37]. A meta-analysis of 28 case-control studies provided evidence for an association between the APOE E4 allele and frontotemporal lobar degeneration [38]. A meta-analysis of seven studies, including 2,090 cases and 742 control suggested an association between $A P O E$ E4 mutation and increased risk of recurrent pregnancy loss [39]. A meta-analysis of seven studies with 966 patients and 1,086 controls suggested that the $A P O E$ polymorphisms were assoated with the risk of psoriasis, especially E2 and E3 alleles [40]. A meta-analysis of experimental and human studies suggested an association between $A P O E$ gene expression and its gene polymorphism with nephrotic syndrome susceptibility [41]. A metaanalysis of 6977 subjects provides evidence that $A P O E \mathrm{E} 2$ mutation is associated with multiple sclerosis risk [42]. A meta-analysis of 29 studies included 1,763 cases and 4,534 controls provided evidence for an association between $A P O E$ gene polymorphisms and the risk of vascular dementia [43]. A meta-analysis of 17 studies, including 1,773 cases and 2,751 controls, revealed that $A P O E$ gene $\mathrm{E} 4$ allele was a risk factor of gallbladder stone disease, especially in elder people and Chinese population [44]. 
Some limitations of this study should be noted. First of all, this is a hospital based case control study, so the selection bias cannot be avoidable and the subjects may not be representative of the general population. Second, the sample size of this study is relatively small, which may not have enough statistical power to explore the real association. Third, these results should be interpreted with caution because the population was only from China, which reduces the possibility of confounding from ethnicity, so it does not permit extrapolation of the results to other ethnic groups.

\section{Conclusion}

In conclusion, our study suggested that $A P O E$ E3/E4 genotype was associated with a higher LEDVT risk. When stratifying by family history of LEDVT, it was found that patients with positive family history of LEDVT had a significantly higher frequency of $A P O E$ E3/E4 genotype. Additional studies are needed to confirm this finding.

\section{Competing interest}

The authors declare that they have no competing interests.

\section{Authors' contributions}

SLZ and ZGW carried out the molecular genetic studies and drafted the manuscript. XPW and YS carried out the genotyping. YS, DXL participated in the design of the study and performed the statistical analysis. SLZ, ZGW conceived of the study, and participated in its design and coordination and helped to draft the manuscript. All authors read and approved the final manuscript.

\section{Acknowledgements}

We thank Drs. Yong Zhou for providing helpful information.

\section{Author details}

${ }^{1}$ Institute of Ultrasound Imaging, The Second Affiliated Hospital, Chongqing Medical University, 76 Riverside Road, Yuzhong District, Chongqing 400010, P. R. China. ${ }^{2}$ Institute of Ultrasound Imaging, Mentougou Hospital, Beijing 102300, P. R. China. ${ }^{3}$ Institute of Ultrasound Imaging, The First Affiliated Hospital of Inner Mongolia Medical University, Huhhot 010059, China.

Received: 24 December 2013 Accepted: 9 January 2014

Published: 24 January 2014

\section{References}

1. Casella IB, Bosch MA, Sabbag CR: Incidence and risk factors for bilateral deep venous thrombosis of the lower limbs. Angiology 2009, 60:99-103.

2. Habscheid W, Hohmann M, Wilhelm T, Epping J: Real-time ultrasound in the diagnosis of acute deep venous thrombosis of the lower extremity. Angiology 1990, 41:599-608.

3. Archie JP Jr, McDaniel DN, Dean VH, Jester JE, Hall DC: Doppler ultrasound evaluation for lower extremity deep venous thrombosis in a community hospital. N C Med J 1989, 50:457-460.

4. Rosendaal FR: Risk factors for venous thrombotic disease. Thromb Haemost 1999, 82:610-619.

5. Muller-Buhl U, Leutgeb R, Engeser P, Achankeng EN, Szecsenyi J, Laux G: Varicose veins are a risk factor for deep venous thrombosis in general practice patients. Vasa 2012, 41:360-365.

6. Chandrakasan S, Sood S, Ham S, Moltz K, Frey MJ, Rajpurkar M: Risk factors and management of deep venous thrombosis in children following post-surgical hypopituitarism in craniopharyngioma. Pediatr Blood Cancer 2011, 57:175-177.

7. Niki Y, Matsumoto H, Hakozaki A, Mochizuki T, Momohara S: Rheumatoid arthritis: a risk factor for deep venous thrombosis after total knee arthroplasty? Comparative study with osteoarthritis. J Orthop Sci 2010, 15:57-63.
8. Koopman K, Uyttenboogaart M, Vroomen PC, van der Meer J, De Keyser J, Luijckx GJ: Risk factors for cerebral venous thrombosis and deep venous thrombosis in patients aged between 15 and 50 years. Thromb Haemost 2009, 102:620-622.

9. Varga EA, Kujovich JL: Management of inherited thrombophilia: guide for genetics professionals. Clin Genet 2012, 81:7-17.

10. Rosendaal FR, Reitsma PH: Genetics of venous thrombosis. J Thromb Haemost 2009, 7(Suppl 1):301-304.

11. Mahley RW: Apolipoprotein E: cholesterol transport protein with expanding role in cell biology. Science 1988, 240:622-630.

12. Poirier J: Apolipoprotein E in animal models of CNS injury and in Alzheimer's disease. Trends Neurosci 1994, 17:525-530.

13. Mahfouz RA, Sabbagh AS, Zahed LF, Mahfoud ZR, Kalmoni RF, Otrock ZK, Taher AT, Zaatari GS: Apolipoprotein E gene polymorphism and allele frequencies in the Lebanese population. Mol Biol Rep 2006, 33:145-149.

14. Laskowitz DT, Horsburgh K, Roses AD: Apolipoprotein E and the CNS response to injury. J Cereb Blood Flow Metab 1998, 18:465-471.

15. Boulenouar H, Benchekor SM, Meroufel DN, Hetraf SA, Djellouli HO, Hermant X, Grenier-Boley B, Medjaoui IH, Mehtar NS, Amouyel P, et al: Impact of APOE gene polymorphisms on the lipid profile in an Algerian population. Lipids Health Dis 2013, 12:155.

16. Eichner JE, Dunn ST, Perveen G, Thompson DM, Stewart KE, Stroehla BC: Apolipoprotein E polymorphism and cardiovascular disease: a HuGE review. Am J Epidemiol 2002, 155:487-495.

17. Loktionov A, Vorster H, O'Neill IK, Nell T, Bingham SA, Runswick SA, Cummings $\mathrm{JH}$ : Apolipoprotein $\mathrm{E}$ and methylenetetrahydrofolate reductase genetic polymorphisms in relation to other risk factors for cardiovascular disease in UK Caucasians and Black South Africans. Atherosclerosis 1999, 145:125-135.

18. Smalinskiene A, Petkeviciene J, Luksiene D, Jureniene K, Klumbiene J, Lesauskaite V: Association between APOE, SCARB1, PPARalpha polymorphisms and serum lipids in a population of Lithuanian adults. Lipids Health Dis 2013, 12:120.

19. Nagato LC, de Souza Pinhel MA, de Godoy JM, Souza DR: Association of ApoE genetic polymorphisms with proximal deep venous thrombosis. J Thromb Thrombolysis 2012, 33:116-119.

20. Katrancioglu N, Manduz S, Ozen F, Yilmaz MB, Atahan E, Ozdemir O, Berkan O: Association between ApoE4 allele and deep venous thrombosis: a pilot study. Clin App/ Thromb Hemost 2011, 17:225-228.

21. Chen XD, Tian L, Li M, Jin W, Zhang HK, Zheng CF: Relationship between endothelial cell protein $C$ receptor gene $6936 \mathrm{~A} / \mathrm{G}$ polymorphisms and deep venous thrombosis. Chin Med J (Engl) 2011, 124:72-75.

22. Hillarp A, Zoller B, Svensson PJ, Dahlback B: The 20210 A allele of the prothrombin gene is a common risk factor among Swedish outpatients with verified deep venous thrombosis. Thromb Haemost 1997, 78:990-992.

23. Lotta LA, Tuana G, Yu J, Martinelli I, Wang M, Yu F, Passamonti SM, Pappalardo E, Valsecchi C, Scherer SE, et al: Next-generation sequencing study finds an excess of rare, coding single-nucleotide variants of ADAMTS13 in patients with deep vein thrombosis. J Thromb Haemost 2013, 11:1228-1239.

24. Acquila M, Bicocchi MP, Mori PG, Odino S, Valetto A, Bottini F: A homozygosity state for 20210A prothrombin variant in a young woman as cause of a deep venous thrombosis during pregnancy. Eur J Haematol 2000, 65:80-81.

25. Akhter MS, Biswas A, Ranjan R, Sharma A, Kumar S, Saxena R: The nitric oxide synthase 3 gene polymorphisms and their association with deep vein thrombosis in Asian Indian patients. Clin Chim Acta 2010, 411:649-652.

26. Van Hylckama VA, Komanasin N, Ariens RA, Poort SR, Grant PJ, Bertina RM, Rosendaal FR: Factor XIII Val34Leu polymorphism, factor XIII antigen levels and activity and the risk of deep venous thrombosis. Br J Haematol 2002, 119:169-175.

27. Austin H, De Staercke C, Lally C, Bezemer ID, Rosendaal FR, Hooper WC: New gene variants associated with venous thrombosis: a replication study in White and Black Americans. J Thromb Haemost 2011, 9:489-495.

28. Ahmad-Nejad P, Dempfle CE, Weiss C, Bugert P, Borggrefe M, Neumaier M: The G534E-polymorphism of the gene encoding the factor VII-activating protease is a risk factor for venous thrombosis and recurrent events. Thromb Res 2012, 130:441-444.

29. Horakova K, Chylkova A, Kolorz M, Bartosova L, Pechacek V, Starostka D, Wroblova K: Polymorphism G-308A in the promoter of the tumor necrosis factor-alpha gene and its association with the risk of venous thromboembolism. Blood Coagul Fibrinolysis 2012, 23:316-319. 
30. Bezemer ID, Bare LA, Arellano AR, Reitsma PH, Rosendaal FR: Updated analysis of gene variants associated with deep vein thrombosis. JAMA 2010, 303:421-422.

31. Bouaziz-Borgi L, Nguyen P, Hezard N, Musharrafieh U, Almawi WY, Mahjoub $T$ : A case control study of deep venous thrombosis in relation to factor $V$ G1691A (Leiden) and A4070G (HR2 Haplotype) polymorphisms. Exp Mol Pathol 2007, 83:480-483.

32. Nizankowska-Mogilnicka E, Adamek L, Grzanka P, Domagala TB, Sanak M, Krzanowski M, Szczeklik A: Genetic polymorphisms associated with acute pulmonary embolism and deep venous thrombosis. Eur Respir J 2003, 21:25-30.

33. Alvim RO, Freitas SR, Ferreira NE, Santos PC, Cunha RS, Mill JG, Krieger JE, Pereira AC: APOE polymorphism is associated with lipid profile, but not with arterial stiffness in the general population. Lipids Health Dis 2010, 9:128.

34. Bahri R, Esteban E, Moral P, Hassine M, Ben Hamda K, Chaabani H: Apolipoprotein gene polymorphisms and plasma levels in healthy Tunisians and patients with coronary artery disease. Lipids Health Dis 2008, 7:46.

35. Zeljko HM, Skaric-Juric T, Narancic NS, Tomas Z, Baresic A, Salihovic MP, Starcevic B, Janicijevic B: E2 allele of the apolipoprotein E gene polymorphism is predictive for obesity status in Roma minority population of Croatia. Lipids Health Dis 2011, 10:9.

36. Wang QY, Wang WJ, Wu L, Liu L, Han LZ: Meta-analysis of APOE epsilon2/ epsilon3/epsilon4 polymorphism and cerebral infarction. J Neural Transm 2013, 120:1479-1489.

37. Stoumpos S, Hamodrakas SJ, Anthopoulos PG, Bagos PG: The association between apolipoprotein $\mathrm{E}$ gene polymorphisms and essential hypertension: a meta-analysis of 45 studies including 13,940 cases and 16,364 controls. J Hum Hypertens 2013, 27:245-255.

38. Rubino E, Vacca A, Govone F, De Martino P, Pinessi L, Rainero I: Apolipoprotein E polymorphisms in frontotemporal lobar degeneration: a meta-analysis. Alzheimers Dement 2013, 9:706-713.

39. Meng HX, Qi MG, Yi YY, Liu YP: Association between apolipoprotein E gene polymorphism and the risk of recurrent pregnancy loss: a meta-analysis. J Assist Reprod Genet 2013, 30:1547-1552.

40. Han Y, Liu T, Lu L: Apolipoprotein E gene polymorphism in psoriasis: a meta-analysis. Arch Med Res 2013, 44:46-53.

41. Zhou TB, Qin YH, Xu HL: Association of apoE gene expression and its gene polymorphism with nephrotic syndrome susceptibility: a meta-analysis of experimental and human studies. Mol Biol Rep 2012, 39:9347-9354

42. Yin YW, Zhang YD, Wang JZ, Li BH, Yang QW, Fang CQ, Gao CY, Li JC, Zhang LL: Association between apolipoprotein E gene polymorphism and the risk of multiple sclerosis: a meta-analysis of 6977 subjects. Gene 2012, 511:12-17.

43. Yin YW, Li JC, Wang JZ, Li BH, Pi Y, Yang QW, Fang CQ, Gao CY, Zhang LL: Association between apolipoprotein $\mathrm{E}$ gene polymorphism and the risk of vascular dementia: a meta-analysis. Neurosci Lett 2012, 514:6-11.

44. Xue $P$, Niu $W Q$, Jiang $Z Y$, Zheng $M H$, Fei J: A meta-analysis of apolipoprotein E gene epsilon2/epsilon3/epsilon4 polymorphism for gallbladder stone disease. PLoS One 2012, 7:e45849.

doi:10.1186/1476-511X-13-21

Cite this article as: Zhu et al:: Apolipoprotein E polymorphism is associated with lower extremity deep venous thrombosis: color-flow Doppler ultrasound evaluation. Lipids in Health and Disease 2014 13:21.

\section{Submit your next manuscript to BioMed Central and take full advantage of:}

- Convenient online submission

- Thorough peer review

- No space constraints or color figure charges

- Immediate publication on acceptance

- Inclusion in PubMed, CAS, Scopus and Google Scholar

- Research which is freely available for redistribution

Submit your manuscript at www.biomedcentral.com/submit 